IITf Threghold Struss Mentircmenes In Shock-Deformed lopper

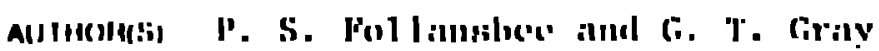

\title{
IISR 'I.AIMF.K
}

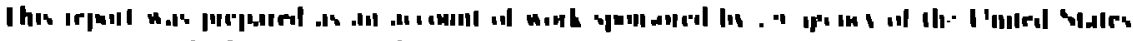

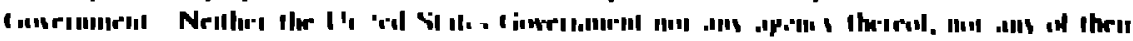

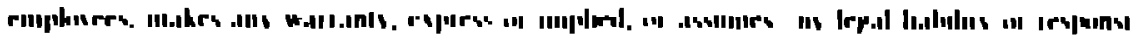

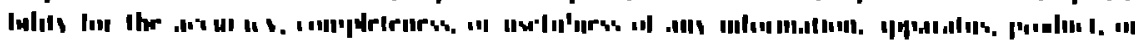

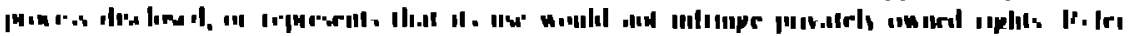

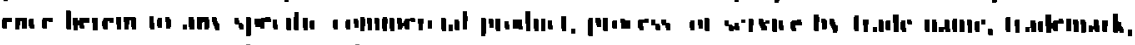

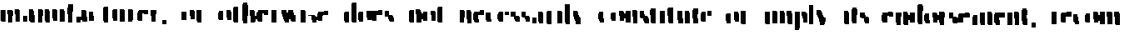

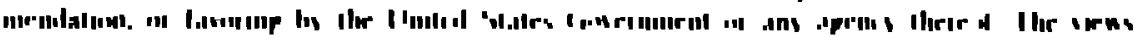

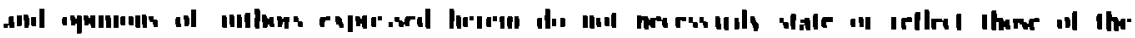

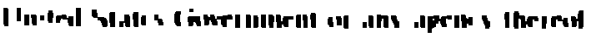

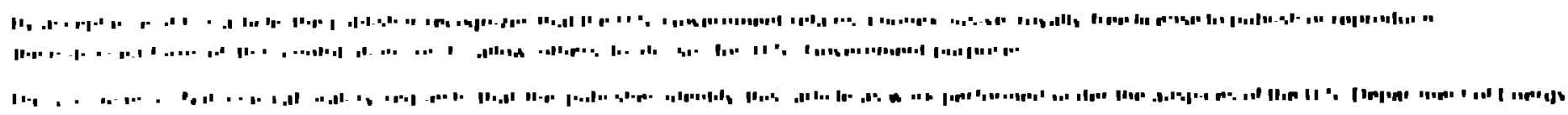


THRESHOLD STRESS MFASURF.MFITS IN

SHOCK-DEFORYTP COPFER

Paul 5. Follanshee and George T. Gray

Los Alapos Nattonal Laboratory

INA Al.gnos, M.M.

\section{IRTRODILTION}

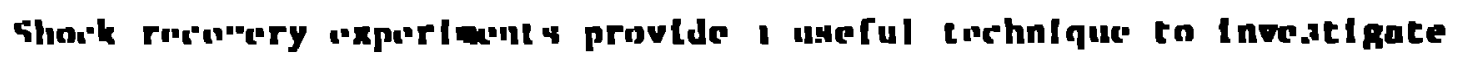

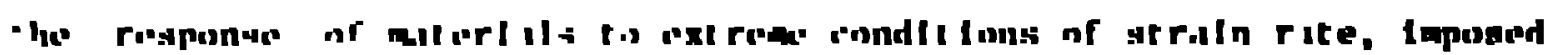

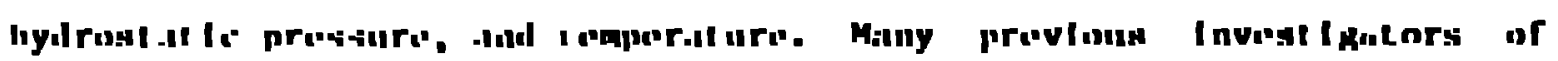

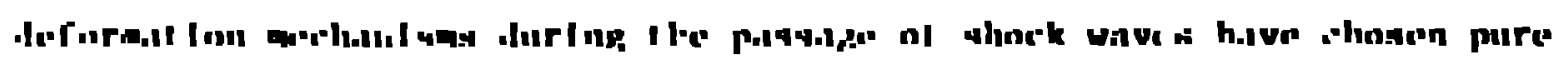

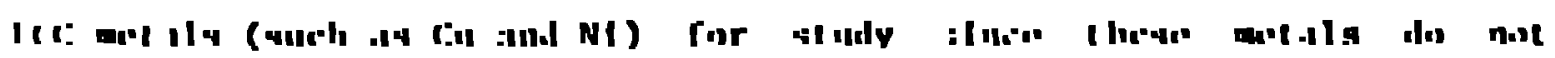

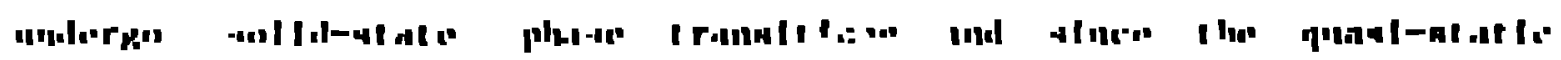

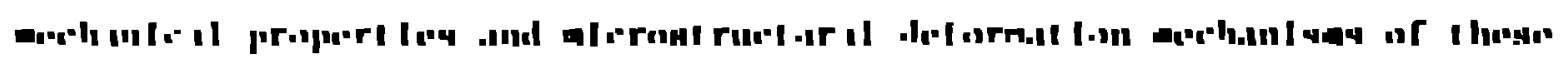

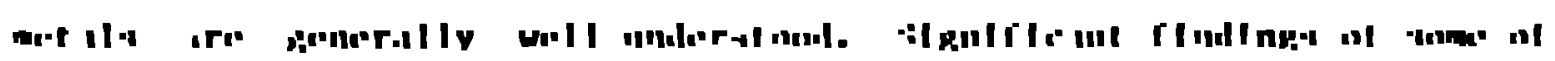

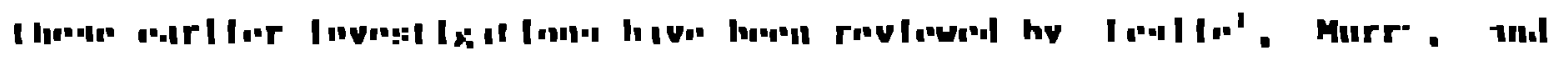

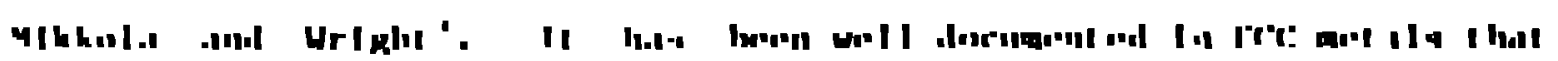

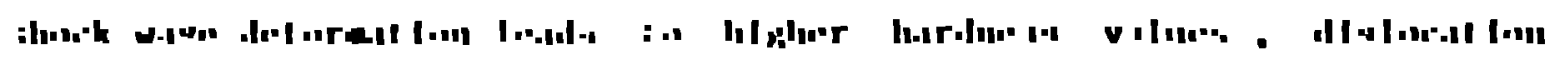

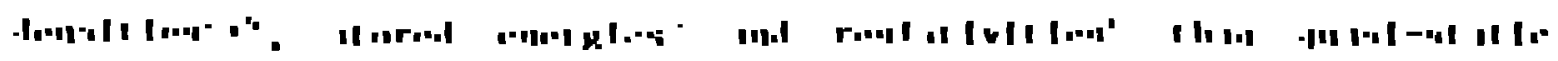

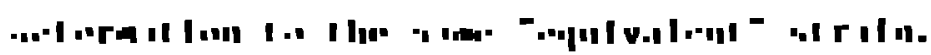


In FCC metals that form distinct cell structures, the coll gize resulting from shock-deformation is typlcally less than that formed quasi-statica11y ${ }^{2}$. One Important difference noted between microstructures formed by shock-deformation and those formed by quasi-static deformation Is the increased contribution of deformation twinning in the latter ${ }^{1}{ }^{3}$. The extent of deformation twinning increases with increasing shoik pressure. Another microstructural difference between quasi-stactc and shock-deformation is the observed increase in the levels of vacancy generation in shock-deformation; evidence for this has been revlewed by Graham ${ }^{7}$.

Summarlzing these previous studles of the shock-deformation behavior of $\mathrm{Cu}$ and $\mathrm{NI}$, one would conclude that at moderate shock pressuras the deformation mechantsms involve dislocation multiplication and dislocation/dislocation Interactions similar to thoye processes that have been documented it quas-state straln rates. As the shock pressute, and thus the imposed otratn rate, Is Increased deformation twiunthg becomes Increasingly Important. The Influence of the nbatrvei Inctused levels of vacancy production on deformation mechunlsms remulns in open quest lon.

In FC, metale the realatince thit a dislocitlon experlences is it

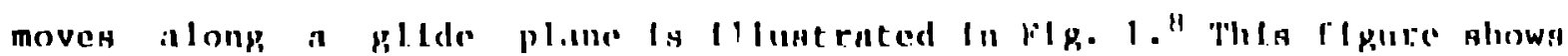

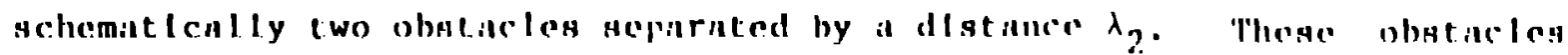

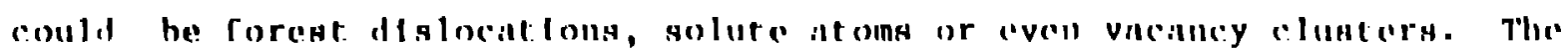

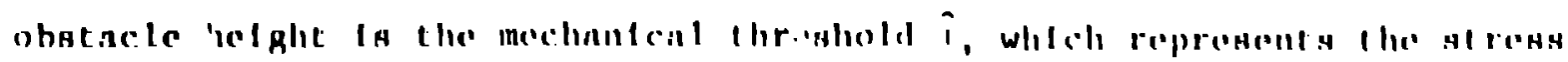

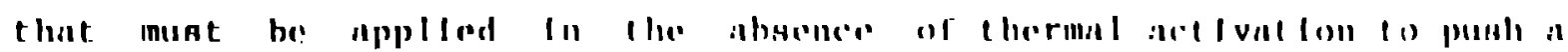


dislocation past the obstacle. At quasi-static otrain rates thermal activation assigts the applied atress and allows dislocation motion at stresses below $\hat{\tau}$. Under dynamic conditions the applied stress may actually exceed $\hat{\tau}$; in this case, the velocity of the dislocation as it moves the distance $\lambda_{2}$ between obstacles becomes rate controlling. One Important consequence of the glide resistance profile for FCC metals shown In Fig. I Ig that during transit between obstacles the stress driving the dislocation velocity is essentially the applied otress. In other crystal structures, a lattice frlction or Pelrel's stress component may oppose the applied otress.

The helght and shape of the obstacle profile for tie dominant obstacle provide information on the nature of the deformed microstructure. These quantlties can he meanured on recovered shock-deformed material using the technique outlined pleviously,$: 0$. The purpose of this paper ts to Eurther Investigate shock wave deformation mechanlsms by measurtng the meihanical threshold, or threshold atress, on shock deformed material. oxygen-free-electronle (OFli) copper was selected for thls atudy stnce tito shock-deformation behnvior nas heen extenstvely otudled ind since these shock-deformation resultis complement extenelve measurementgll nt htraln rales up to $10^{\prime \prime} H^{-1}$. Mcanuremente or the mechunleal throphold, thetr Implications regarding deformetion mochanlsms ind correlintion with the

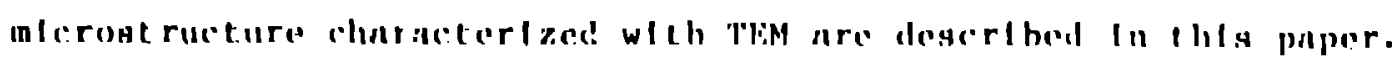


FXPERIMENTAL

The OFE $\mathrm{Cu}$ was obtained in the form of $12.7 \mathrm{~mm}$ thick plate. Specimens for the shock recovery experiment, to be detalled below, werc machined from this starting material and annealed at $600 \mathrm{C} \mathrm{in}$ vacuum for one hour to yleld the desired reciygtallized gcaln gtructure with equiaxed Sraing of $4 \mathrm{C} \mu \mathrm{m}$ average dimension.

The shock recovery experiments were performed utilizing a 40 um olngle-stage gas gun. The specimen configuration used consisted of a 4.76 mm thlck, $12 \mathrm{~mm}$ diameter tapered $\left(10^{\circ}\right)$ sample tightly fitting into two concentric copper momentum trap rings with outgide diameters of 25 mm and 42. $\mathrm{mm}$ (F1g. 2). The sample surface was protected from impact and the entire sample from spallation by a close-fitting copper cover plate (2.5 am thick) and spall plate (12 $\mathrm{mm}$ thick), respectlvely. $\Lambda 11$ spectmen asaembly components were machined to a $\| 32$ or better finish and separated by a thin layer of vacuum grease to ellminate "hot spots" during the shock-1oading process. The taper, concentric momentum rings, and component surface fintsi: have been found by previous design teating to mintmlze converglng relense whve oflecta resulting In nearly pire unlaxial londing and rolenge wtth lette restdunl. sample straln.

The copper sumple was shocked to lo Gip for : lis puls: duratou by Impact Lng n $2.20 \mathrm{~mm}$ lhick copper flyer plate, fixed to a Iow-linpedince

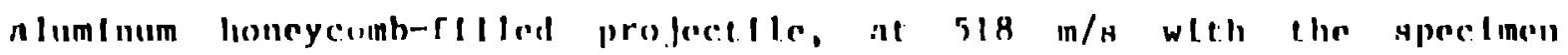

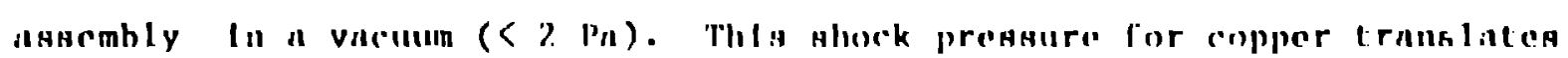


Into a transient strain of 0.0825 using the relation $\varepsilon_{s}-4 / 3 \mathrm{ln}\left(\mathrm{v} / \mathrm{v}_{0}\right)$. Foliowing the removal of the shock-loaded specimen frow a water-recovery cank, four compression specimens were electron-discharge machined (EDM) from the recovered disc. Th1ckness measurements following shock-loading revealed a final sample thickness varying over the sample between $4.63 \mathrm{~mm}$ and $4.70 \mathrm{~mm}$ compared to a pre-shot thickness of $4.72 \mathrm{~mm}$. The compression spectmens averajed $4.5 \mathrm{~mm}$ in length by $4.3 \mathrm{~mm}$ in diameter. It should be emphasized that for these experiments no precautions were taken to minimize recovery processes in the time period between the shock-deformation and the quasi-static reloading.

The reloading operation was performed at a strain rate of $0.0015 \mathrm{~s}^{- \text {: }}$ with a screw-driven mechanical testing machine equipped with a specially designed subpress which could be completely tmmersed in liquid nitrogen. Two specimens were reloaded at room temperature (297 K) while the remalning two were reloaded at liquid nitrogen temperature (76 K).

Samples for optical metallography and transmisolon electron mlcroscopy (TFM) were sectloned from the pleces of the shock-deformed disc whlch remalned after the compression spectmuns were removed. Wafers for THM examination were Inttlally chemleally thinned to $0.11 \mathrm{~mm}$ in a solution of $50 \% \mathrm{I}_{3} \mathrm{PO}_{4}, 40 \%$ UNO 3 and $10 \% \mathrm{HCl}$ at $25 \mathrm{c}$. $91 \mathrm{gecs} 3 \mathrm{~mm} \mathrm{In}$ dlameter were then punched and electropollahed In a wolut on of $25 \% \mathrm{I}_{3} \mathrm{PO}_{4}$ and $75 \% \mathrm{II}_{2} \mathrm{O}$ it 0 c attllzlng i current drently of $80 \mathrm{~m} \Lambda / \mathrm{mm}^{\prime}$. Observetion of the folls

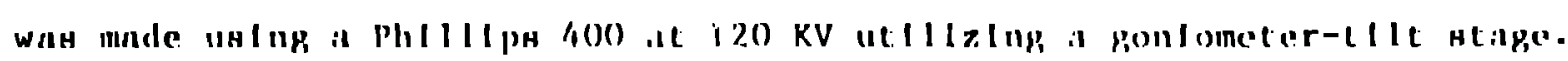


RESULTS

\section{Mechantca1 Threshold Measurements}

The four otress strain curves for the reloads at $297 \mathrm{~K}$ and $76 \mathrm{~K}$ are shown In Fig. 3. There is a hint of a yleld drop for the $297 \mathrm{~K}$ curvea, which is not evident in the $76 \mathrm{~K}$ curves. These results are siullar to those reported by Appleton and Waddington using tensile reloadsl. The yleld polnts, determined by back-extrapolating the work hardening behavior at otraing to $E=0.10$, lor $t_{1}: 297 \mathrm{~K}$ curves are $245 \mathrm{MPa}$ and 249 Mta while those for the $76 \mathrm{~K}$ curves are $307 \mathrm{MPa}$ and $313 \mathrm{MPa}$.

The mechanical threshold is the $y$ teld stress at $0 \mathrm{~K}$, which we determine hy extrapolation. The extrapolation procedure, which has been described previously,$: 0$, is outlined below. For the quagt-atatic strain rate of the reload experiments, the deformation is thermally ectivated and can be represented by an equation of the form

$$
\begin{aligned}
& \dot{E}-\dot{B}_{0} \exp -\frac{\Lambda G}{k T}, \\
& \text { where } \quad \dot{\theta}_{0}=\frac{p_{\ln }{ }^{b} \lambda_{2}}{M v_{0}-1}
\end{aligned}
$$

and $A\left(\right.$ i tg the activation energy. In Fq. 2 , $P_{m}$ is the moblle dislucation denstey, b lis the isurgers vector, M La the Taylor factor, nnd $v_{0}$ Ls the ntempt frequency. When short range obatacles are rate controlling, the not tvition energy cals be approximntend by"

$$
\Lambda c=\| b^{3} g_{0} \mid 1-\left(\begin{array}{c}
0 \\
a
\end{array}\right)^{11: 1 / 2} \text {. }
$$


where $B_{0}$ is the normalized activation energy. The exponents $1 / 2$ and $3 / 2$ In Eq. 3 are chosen to represent the obstacle profile for short range obstacles ${ }^{8}$.

Extrapolation to $0 \mathrm{~K}$ requires that the temperature dependence of the activation energy $\Delta G$ be added to the intrinsic temperature dependence ( $k T$ ) given by Eq. 3. Assuming that the temperature dependence of the activation energy $1 \mathrm{~s}$ equal to that of the shear modulus $\mu$, $\Delta G(T)=\mu(T) b^{3} g_{0}$, then the extrapolation to $0 K 18$ given by combining and rearranging Eqs. 3 and 1 to give

$$
\left(\frac{\sigma}{\mu(T)}\right)^{1 / 2}=\left(\frac{\hat{l}}{\mu(T)}\right)^{1 / 2}\left\lfloor 1-\left(\ln \frac{\varepsilon_{0}}{E} \frac{k T}{\mu(T) b^{3} B_{0}}\right)^{2 / 3}\right\rfloor .
$$

If the normalization procedure with respect to temperature is currect, then a plot of $(\sigma / \mu(T))^{1 / 2}$ versus $\left(k T / \mu(T) b^{3}\right)^{2 / 3}$ for the reload experiments at constant otraln rate but varylng temperature should yteld a stra!ght line. The intercept at zero temperature In this plot glves the mechanlcal threshold normalized by the shear modulug while the slope lis Inversely related to the normalized nctivation energy. The data from the reload expertments nre plotted on these coordinates in Fig. 4. Included I.n Fig. 4 are results ohenlned prevtously|l at a straln of 0.10 and straln races of $0.0014 \mathrm{~s}^{-1}, 0.82 \mathrm{~s}^{-1}$ and $5000 \mathrm{~s}^{-1}$. These latter data include reload expertments it $200 \mathrm{~K}$ whlch glves data at three Lemperitures and alows an evaluntion of the normaltzation procedure demerlbed athove is well as of che exponent., chosen In fil. 3. No testas at the Intorinedlente 


\begin{abstract}
$-8-$
temperature could be performed on the shock recuvered specimens due to the ilmitad number of samples. The values of the mechanical threshold (referenced to $297 \mathrm{~K}$ ) and the normalized free energy for the shock recovered material are listed in Table 1 along with previously obtained values for lower strain rates. The latter data are grouped into two categorles to show compazisons at uniform strain as well as at uniform mechanical threshold.
\end{abstract}

\begin{tabular}{|c|c|c|c|c|}
\hline & $\underline{\varepsilon}$ & $\dot{\mathrm{E}}$ & $\hat{\tau}(297 \mathrm{~K})$ & so \\
\hline 10 GPa Shock & .0825 & (10 GPa) & 314 & $0.80 \times 10^{21} \mathrm{Nt}-\mathrm{m}$ \\
\hline $\begin{array}{l}\text { Untform } \\
\text { Strain }\end{array}$ & $\begin{array}{l}.10 \\
.10 \\
.10 \\
.10 \\
.107 \\
.10 \\
.087\end{array}$ & $\begin{array}{l}.00014 \mathrm{~s}^{-1} \\
.015 \\
.82 \\
81 \\
1800 \\
5000 \\
9500\end{array}$ & $\begin{array}{l}179 \mathrm{MPa} \\
187 \\
191 \\
204 \\
218 \\
228 \\
212\end{array}$ & $\begin{array}{l}9.4 \\
5.7 \\
6.0 \\
1.9 \\
6.8 \\
3.3 \\
4.8\end{array}$ \\
\hline $\begin{array}{l}\text { Uniform } \\
\text { Mechanical } \\
\text { Threghold }\end{array}$ & $\begin{array}{l}.25 \\
.25 \\
.209 \\
.211\end{array}$ & $\begin{array}{l}.82 \\
81 \\
1800 \\
5000\end{array}$ & $\begin{array}{l}309 \\
329 \\
309 \\
325\end{array}$ & $\begin{array}{l}2.07 \\
1.88 \\
2.08 \\
1.43\end{array}$ \\
\hline
\end{tabular}

In the previous study, mechanical threshold values were obtained as a function of atraln. By Interpolating these rcsults, we have plotted in Flg. 5 the mechantcal threshold values at a single straln of 0.0825 , whlch corresponds to the translent platelc straln during the shork-deformation. The actunl otraln rate for the 10 (IPa shock lo unknown and, In fact, probnbly varles HLgnlflcimlly between the loading and unloadlng portions of tile wave. For Flg. 5 the striln rite durlug the shock $t$ s assumed to 
lie within the range $10^{5} \mathrm{~s}^{-1}$ to $10^{6} \mathrm{~g}^{-1}$; the lower $11 \mathrm{mit}$ 1s set by the transient gtrain divided by the pulse duration.

\section{Substructure Observations}

Optical and TEM m1crographs of the $10 \mathrm{GPa}$ shock-deformed copper are shown in F1g8. 6 - 8. The micrographs reveal evidence of a highly dislocated structure with a percentage of grains exhibiting fine parallel markings (seen optically in Fig. 6) which TEM and selected-area diffraction (SAD) analysis verify as deformation twins. The predominant deformation substructural feature, that of dislocation cells, is consistent with numerous previous studies on shork-loading of copper $^{2}, 4,12,13$ at moderate pressures. Dislocation loops were also observed within some cell interiors.

Depending upon orlentation, grains were found to exhibit entirely cellular dislocation, desormation twinned, or a mixed subsiructural morphology. Addittonally a small fraction of gralns exhlbited bands of high dislocation density ${ }^{4}$ lying on $\{111\}$ planes; these may be features Identifled as mlcrobands which have been observed in heaslly cold rolled copper $^{14}$. 
DISCUSSION

The mechantcal threshold measurementg lead to geveral interesting conclusions. The comparisons shown In Table 1 and Fig. 5 Indicate that at equivalent gtratn, the mechanlcal threshold Increases dramatically in the shock-deformation regime. In fact, as shown in F1g. 5, the 1ncrease begins at strain rates closer to $10^{3} \mathrm{~s}^{-1}$. The mechanical threshold $1 \mathrm{~s}$ a mechanical measure of structure, and for dislocation hardening alone the mechanical threghold is related to the total dislocation denatty $\rho$ by 5

$$
\hat{\tau}=\mu b \rho^{1 / 2} \text {. }
$$

If the sole difference between the quasi-static daformation and shock-deformation were In the rate of dislocation storage, then from Eq. 5 and from the data in Table 1 the dislocation density in a shock-deformed sample should be approximately three times that in a sample quasi-gtatically deformed to a strain of 0.10 . While it ts well documented using messurements of realrtivity ${ }^{5}$, energy gtorage ${ }^{5}$, and actual dislocation counts in TFM folls ${ }^{4}$ that the dislocation densities in shock-deformation exceed those in quasi-static deformation, the experimental techniques for measuring the dislocation density are probably not precise enough to verify this factor of three estimate.

The other comparion shown In Table I Is that of the normaliagd activation energy at constant threghold otress. The value for the shock-deformed :aterial, $g_{0}=8.0 \times 10^{20} \mathrm{Nt}-\mathrm{m}, \quad$ Is roughly one-hatf the values at the lower struln rites. Thls supgests that the obstacle In the 
former 1s olightly more rate senstelve than that in the latter. Comparison of the values of $g_{0} a$ : the lower strain rates with those at the higher straln rates in Table 1 shows a general trend toward a decreasing $8_{0}$. However, a fartor of two $1 \mathrm{~s}$ small and, given that the egtimate of $8_{0}$ 1s made from the glope of the fit in Fig. 4, the error In this estimate may be large. For comparison, mechanical threshold measurements on a solid solution hardened austentitc stalnless stee $1^{10}$ ylelded a normalized activation energy equal to $0.5 \times 10^{20} \mathrm{Nt}-\mathrm{m}$, which suggesta that the sma11 difference noted in Table $l$ between the shock hardened material and matertal strained at lower strain rates is probably not significant.

\footnotetext{
Microscopic characterization of the shock-deformed microstructure tends to support the conclustons based on the mechanical threshold measurements. The observed structure was heavily dislocated and contalned well developed cellular structures. At a shock pressure of $10 \mathrm{GPa}$, a few gralns deform solely by deformation twinning while In other gralns both twins and cellular dislocation structures are observed. It is unclear what Influence the twing have on the mechanfcal threshold measurements. Since the Increase in the dependence of the mechantcal threshold on strain rate begins at strain rates as low as $10^{3} \mathrm{~s}^{-1}$, where deformation twinning definitely has not been found, the obgerved twinning at $10 \mathrm{GPa}$ probably has not influenced the mechanical threshold measurements.
}

Although some ohservatlons of the shock-deformed mlcrostructure are consistent wlth highcr Levels of vacancy producton, thls doeg not appear to be a domlnant fenture. The mechument threblold ineasurement. algo show 
no evidence of a drametically increased density of a second, more rate Bensitive, defect, which vacancy loops or clusters might be expected to provide.

The conclusion based on the experimenig described here is that the mechanical threshold measurements are csnsistent with measurenents obtalned at lower gtrain rates. The mechanical threshold of shock-deformed copper exceeds that of quasi-istatically and even dynamically $\left(\dot{\varepsilon}=10^{4} \mathrm{~s}^{-1}\right)$ deformed copper. It appearg as $1 \mathrm{f}$ the high straln rates achleved during the shork process lead to increased levels of dislucation storage, which aze consistent with trendis noted at strain rates exceediny $10^{3} \mathrm{~B}^{-1}$.

Measuremants of the mechantcal threshold provide another tonl with which to study shock-deformation mechanisms. These expertments should be extended to other materials and to the Invegtigation of efferts of peak pressure, pulse duration and ratefaction rate on the structure evolution durting shock-deformat Ion.

ACKNOWLFDGFMTENTS

The authors wh th to neknowledge (i. Frantz and B. Incquez for thelr

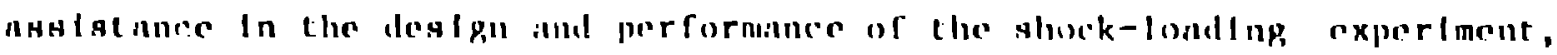
M. lopez for hls ciphblo optloil motillogriphy skllla, and l' Martla for

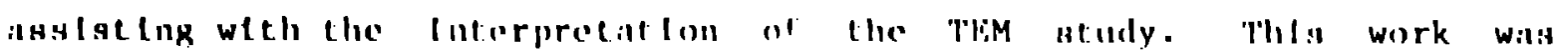

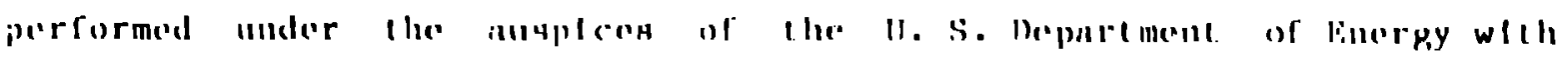


support from the Los Alamos National Laboratory Center for Materials

Science.

\section{REFERENCES}

1. W. C. Leslie, Microstructural effects of high gtraln rate deformation, 1n: "Metallurgical Effects at High Strain Ratea," R. W. Rohde, B. M. Butcher, J. R. Holland, and C. H. Karnes, eds., Plenum Prese, New York (1973).

2. L. E. Murr, Residual microstructure-mechanicel rroperty relationships In shock-loaded metals and alloys, In: "Shock Waves and H1gh-Strain-Rate Pheromena in Metals," M. A. Meyers and L. E. Murr, eda., Plenum Presg, New York (1981).

3. D. E. Mikkola and R. N. Wright, Metallurglcal effects of shock load1ng, In: "Shock Waves in Condensed Matter-1981," W. J. Ne111s, L. Secman, and R. A. Graham, eds., American Institute of Physlcs, New York (1982).

4. J. George, An electron microscope investigation or explosively loaded copper, Phil. Mag. 15:497 (1967).

5. D. C. Brillihart, R. J. De Arigel:s, A. G. Preban, J. B. Cohen and P. Gordon, Quantitative study of the substructure and properties of shock-loaded copper, AIME Tran.s. 239:836 (1967).

6. H. Kressel and N. Brown, Lattlce dcfects in shock-deformed and cold-worked nickel. J. Appl. Phys. 38:1618 (1967).

7. R. A. Graham, Actise measurements of defect processes in shock-compressed metals and other sollds, In: "Shock Waves and High-Strain-Rate Phenomena In Metals," M. A. Meyers and L. E. Murr, eds., Plenum Press, New York (1981).

8. U. F. Kocks, A. S. Argon and M. F. Ashby, "Thermodynamich and KInet lcs of S11p," Prog. Mt l. Sc1. 19, Fergnmon Press, New York (1975).

9. P. S. Follansbee, G. Regazzont and li. F. Kocks, The tranaltion to drag-contiolled deformation in copper at high otraln rates, In: "Mechantcal Propertles at High Rates of Strain," Tnst. Phys. Conf. Ser. No. 70, J. Harding, ed., Institute of Physlcs, London (1984).

10. P. S. Follansbee, U. F. Kocks and G. Regurzonl, The mechanical threshold of dynamicaliy deformed copper and Nitronic 40, to he published in: "proceedings of the International Conference on Mechantcal and Pliystcal Rahavior of Mntorlal under Dynamic Londing," Parta, Frunce (1985).

11. A. S. Appleton and .I. S. Wnddlnpton, Sning obaervatione of discont tnuous yleldlug phenomena in ocpper, nlckel and alumlnun after Hhock lnadtnk, Phll. Mng. 12:273 (1965).

1.2. A. S. Appleton and .J. S. Wriditupton, The linportince of shock wuve profile tn exploalue londlup expertinenta, Actin Met. 12:950 (190/).

13. 0). Iohnrl and (i. Thomis, Substructuren In oxplosively deformad cul and Cu-Al alloys, Actu Mot. 12:1153 (196il).

14. A. S. Malla and M. ilietherly, Mlcrostructuren of enlat-rolled eopper, Methl ScI. 77:167 (1973). 
$-14-$

15. H. Mecking and U. F. Kocks, Kinetics of flow and gtrain hardening, Acta Met. 29:1865 (1981). 


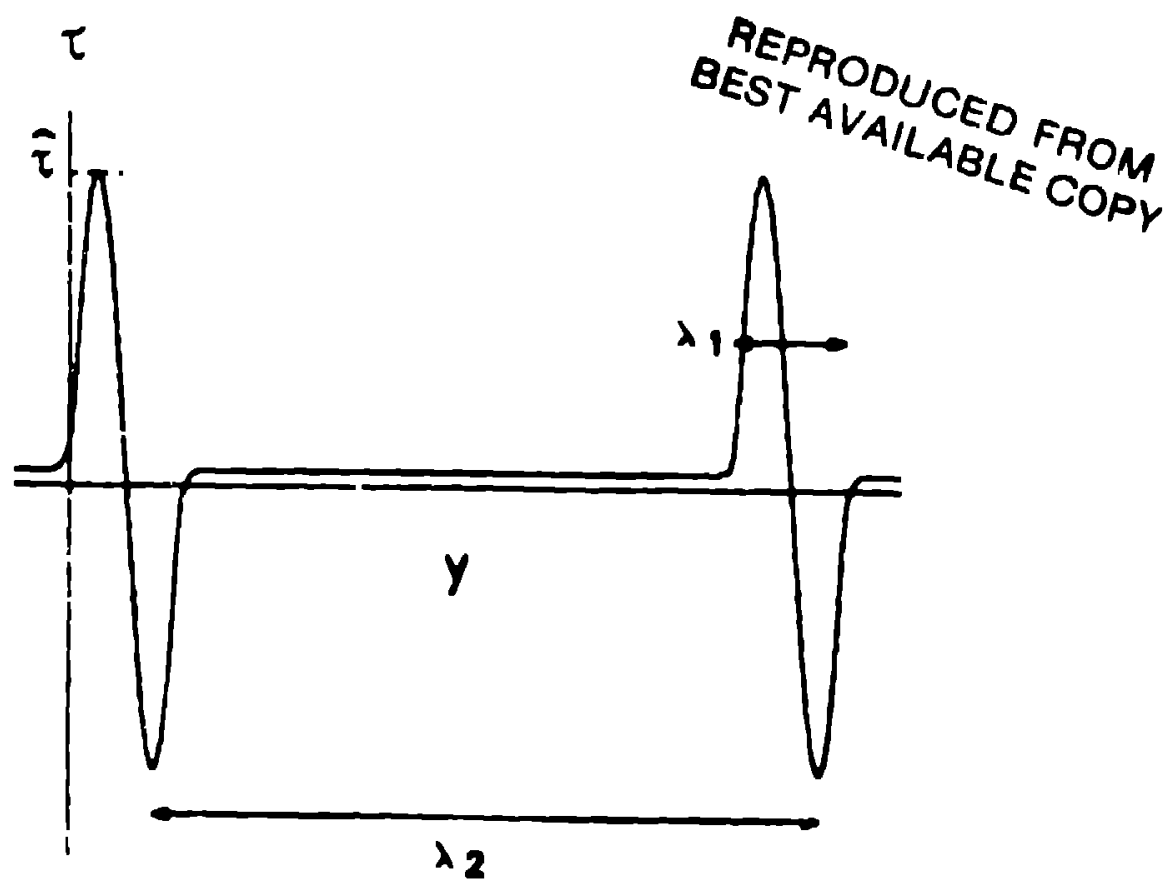

Figure 1: Glide resistance profile showing the interaction between a mobile dislncation and two short range $\left(\lambda_{1} \ll \lambda_{2}\right)$ obstacles separted by a distance $\lambda_{2}$.

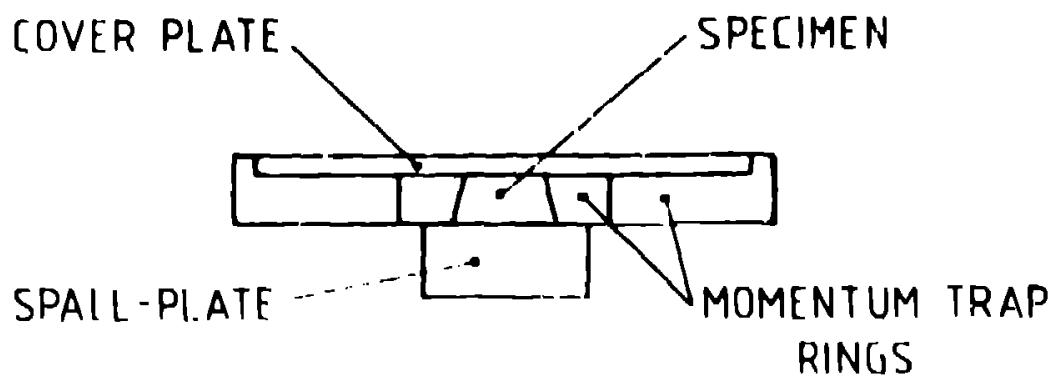

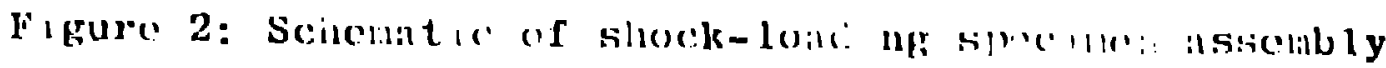




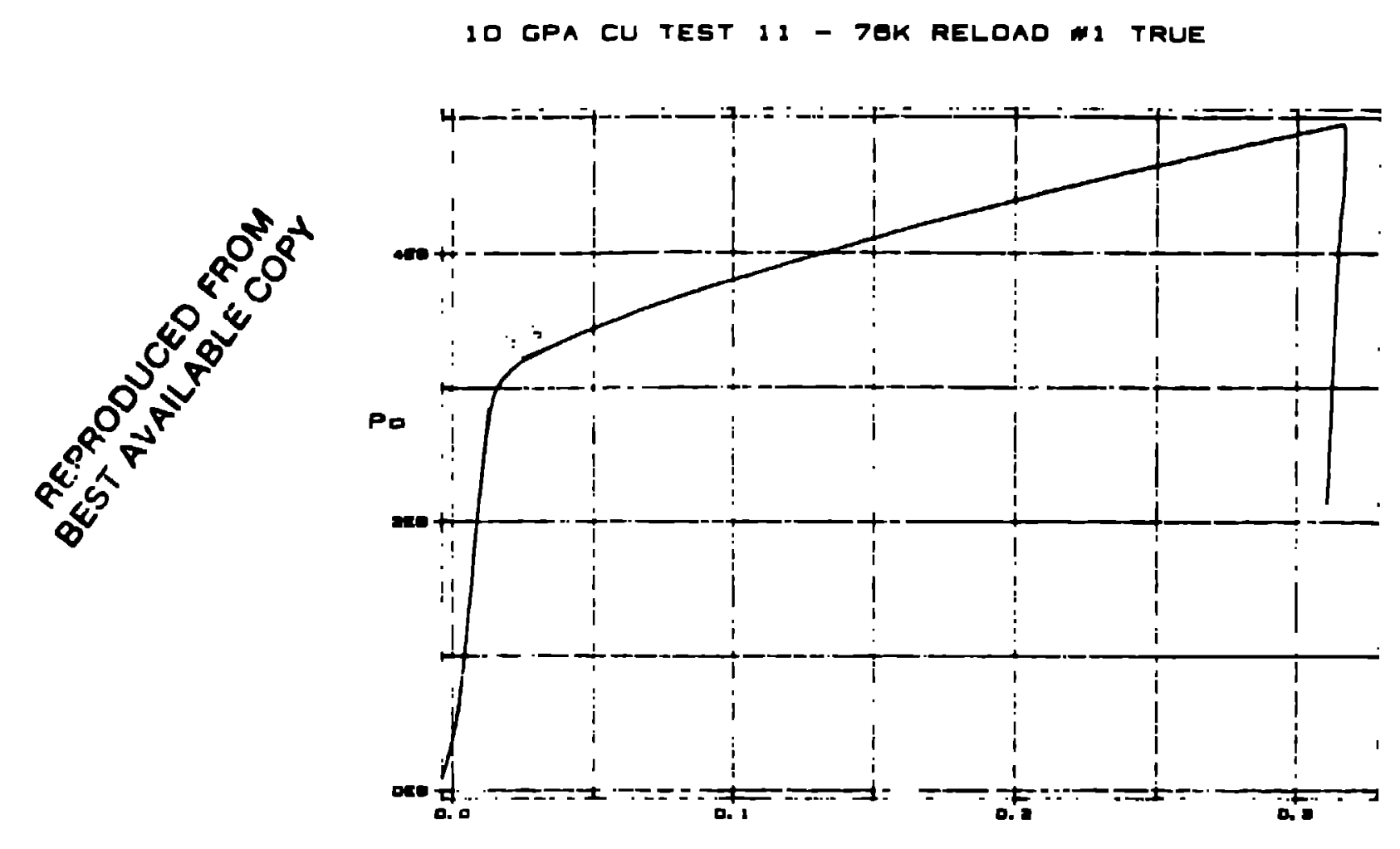

$\therefore:$

1 LI CIFA rII TEGT 11 - RT REI.OAAT MG TRIJE:

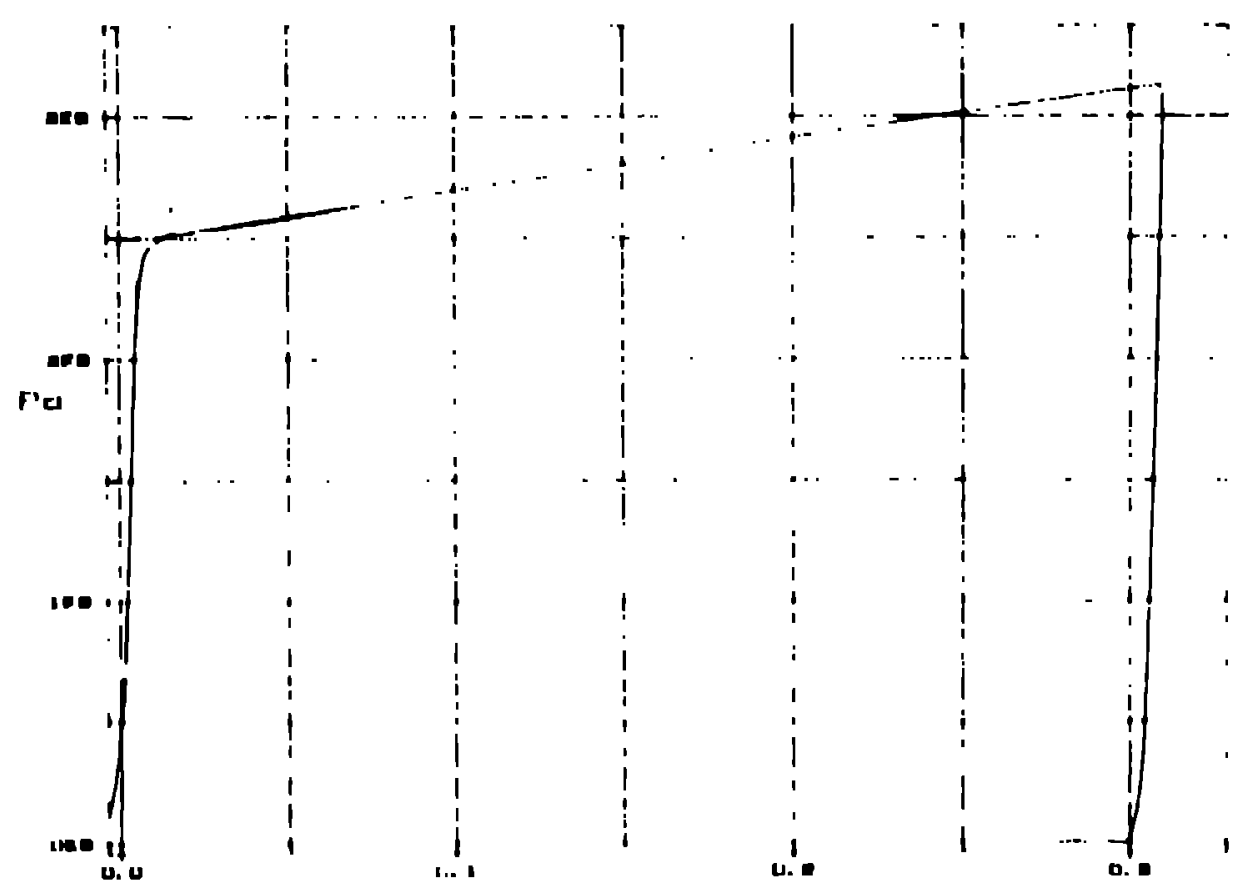

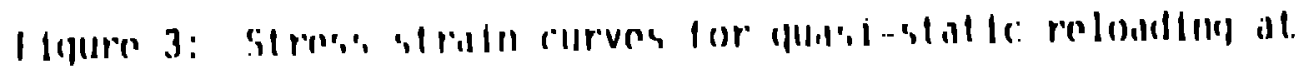

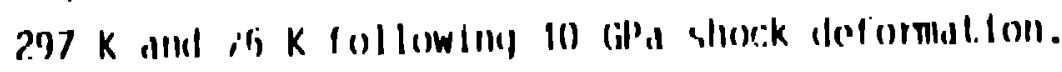



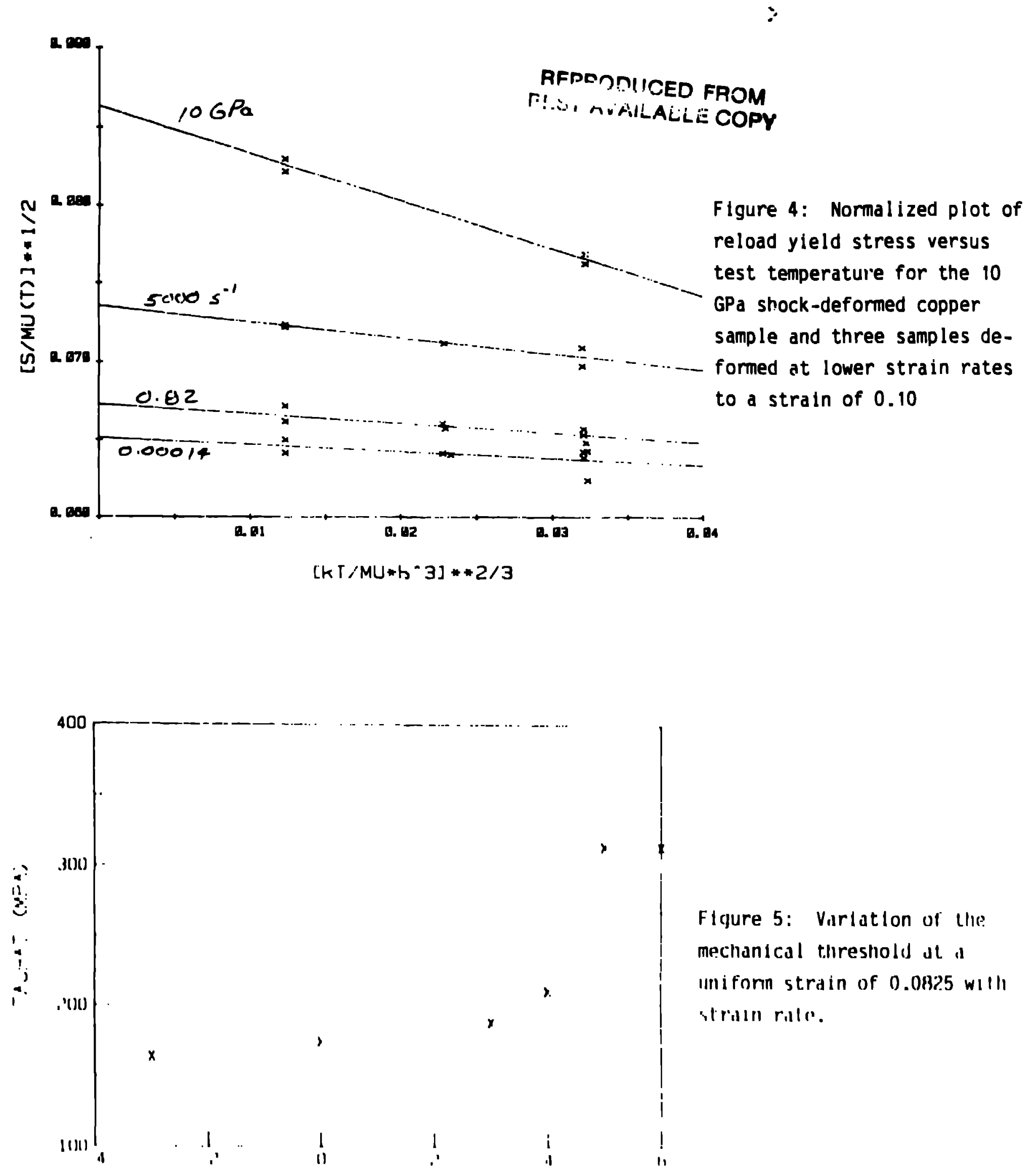

IIIT IIIRAIN RAII 

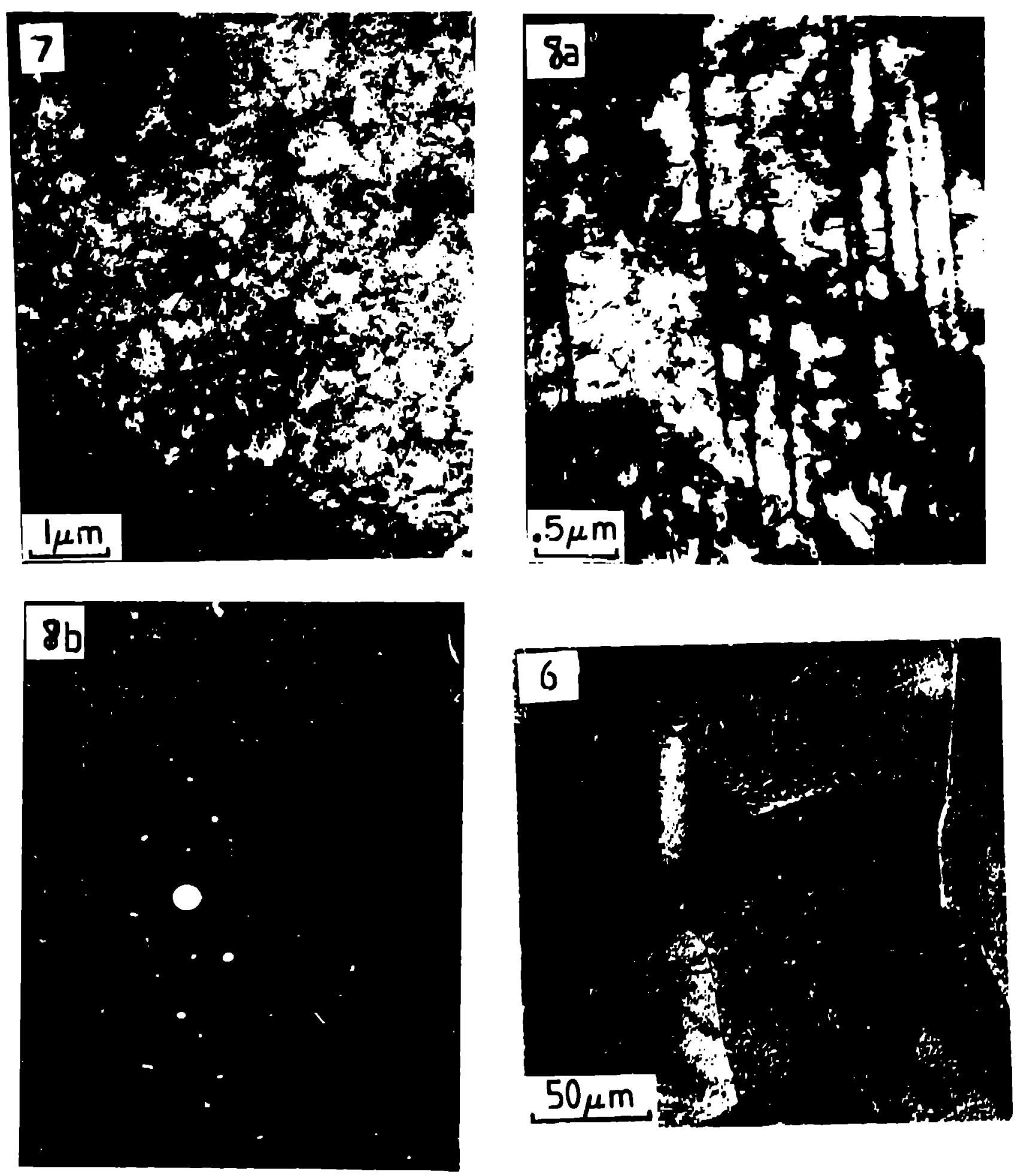

Flyure 6: Optlcal microyraph of shock-cleformed copper showing twinned and heavlly dislociated (otch plts) structure.

Floure 1: Brlght fleld alectron mlcrograph of collular dli, locallon substructuro In shock-loaded copper $\langle ? 13\rangle$ ronc.

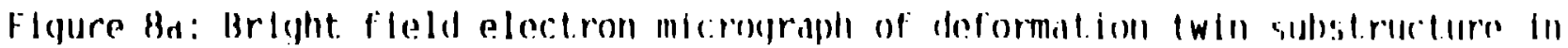
illock-dolormed collpere.

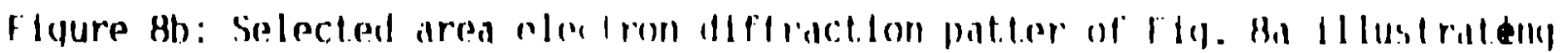
twin reflectloms in $\langle 1111\rangle$ rome. 